\title{
PERBEDAAN KADAR KOLESTEROL TOTAL SEBELUM DAN SETELAH PEMBERIAN SARI BENGKUANG (Pachyrrhizus erosus) PADA WANITA
}

\author{
Nisrina Hanisa, Enny Probosari* \\ Program Studi Ilmu Gizi Fakultas Kedokteran Universitas Diponegoro \\ Jl.Dr.Sutomo No.18, Semarang, Telp (024) 8453708, Email : gizifk@ undip.ac.id
}

\begin{abstract}
Background: Hypercholesterolemia was a condition caused by fat metabolism disorder characterized by high levels of total cholesterol in the blood. One of alternative that can lower cholesterol levels was by arrangement of the diet. The arrangement of diet which is recommended by increasing the consumption of vegetables and fruit. Yam bean was one of food ingredients that can be associated with a decrease in total blood cholesterol levels. This study aimed to determine differences in total cholesterol levels before and after administration of yam bean essence (Pachyrrhizus erosus) in women.

Methods: The study was true experiment with the design of the control group pre test-post test. Subjects were 28 women aged 40-50 years with total cholesterol levels between 200-239 mg / dl. Subjects were divided into two groups, which each group consists of 14 people. The administration was given for the 21 -day intervention with treatment group getting the yam bean essence that obtained from 320 grams of yam bean and the control group received a placebo in the form of low-calorie syrup water. CHOD-PAP method was used to analyze the levels of total cholesterol, blood was taken on day 22 after the subjects fasted for 10 hours. Test for normality was using Shapiro Wilk test. Statistical analysis was using dependent t-test, independent t-test and Mann Whitney.

Results: The mean total cholesterol level of treatment groups before the intervention is $222.64 \pm 10.42$, and after the intervention is $202.64 \pm 14.73$ with $p=0.000$ ( $p<0.05$ ). The mean total cholesterol level of control group before the intervention is $220.14 \pm 10.64$, and after the intervention is $233.07 \pm 19.46$ with $p=0.004(p<0.05)$. There is a significant decrease in total cholesterol in the treatment group after the administration of yam bean essence by 20 $\mathrm{mg} / \mathrm{dl}$. There is a significant increase in total cholesterol levels in the control group after the intervention by 12.3 $\mathrm{mg} / \mathrm{dl}$. There is a significant difference in total cholesterol levels between the control and treatment groups with $p$ $=0.000(p<0.05)$.
\end{abstract}

Conclusion: Consumption of yam bean essence can lower total cholesterol levels significantly by $20 \mathrm{mg} / \mathrm{dl}$ after eating yam bean essence that obtained from 320 grams of yam bean.

Keywords: yam bean ; total cholesterol; hypercholesterolemia

\begin{abstract}
ABSTRAK
Latar Belakang : Hiperkolesterolemia merupakan kondisi akibat gangguan metabolisme lemak yang ditandai dengan tingginya kadar kolesterol total dalam darah. Salah satu alternatif yang dapat menurunkan kadar kolesterol adalah dengan cara pengaturan diet. Pengaturan diet yang dianjurkan adalah dengan cara meningkatkan konsumsi sayuran dan buah. Buah bengkuang adalah salah satu bahan makanan yang dapat dihubungkan dengan penurunan kadar kolesterol total darah. Penelitian ini bertujuan untuk mengetahui perbedaan kadar kolesterol total sebelum dan setelah pemberian sari bengkuang (Pachyrrhizus erosus) pada wanita.

Metode : Jenis penelitian adalah true experiment dengan rancangan control group pre test - post test. Subjek adalah 28 wanita berusia 40-50 tahun dengan kadar kolesterol total antara 200-239 mg/dl. Subjek dibagi menjadi dua kelompok, yang setiap kelompok terdiri dari 14 orang. Pemberian intervensi dilakukan selama 21 hari dengan kelompok perlakuan mendapatkan sari bengkuang yang didapat dari 320 gram bengkuang dan kelompok kontrol mendapat plasebo berupa air sirup rendah kalori. Metode CHOD-PAP digunakan untuk menganalisis kadar kolesterol total, darah diambil pada hari ke-22 setelah subyek berpuasa selama 10 jam. Uji normalitas menggunakan Shapiro Wilk. Analisis statistik menggunakan dependent t-test, independent t-test dan Mann Whitney.

Hasil : Rerata kadar kolesterol total kelompok perlakuan sebelum intervensi sebesar 222,64 $\pm 10,42$, dan setelah intervensi sebesar 202,64 $\pm 14,73$ dengan nilai $p=0,000(p<0,05)$. Rerata kadar kolesterol total kelompok kontrol sebelum intervensi sebesar 220,14 $\pm 10,64$, dan setelah intervensi sebesar 233,07 $\pm 19,46$ dengan nilai $p=0,004$ ( $p<0,05)$. Terdapat penurunan kadar kolesterol total yang bermakna pada kelompok perlakuan setelah pemberian sari bengkuang sebesar $20 \mathrm{mg} / \mathrm{dl}$. Terdapat peningkatan kadar kolesterol total yang bermakna pada kelompok kontrol setelah intervensi sebesar $12,3 \mathrm{mg} / \mathrm{dl}$. Terdapat perbedaan yang bermakna kadar kolesterol total antara kelompok kontrol dan perlakuan dengan nilai $p=0,000(p<0,05)$.
\end{abstract}

Simpulan : Konsumsi sari bengkuang mampu menurunkan secara signifikan kadar kolesterol total sebanyak 20 mg/dl setelah mengonsumsi sari bengkuang yang didapat dari 320 gram buah bengkuang.

Kata kunci : bengkuang; kolesterol total; hiperkolesterolemia

\footnotetext{
${ }^{*}$ Penulis Penanggungjawab
} 


\section{PENDAHULUAN}

Hiperkolesterolemia merupakan kondisi akibat gangguan metabolisme lemak yang ditandai dengan tingginya kadar kolesterol total dalam darah. ${ }^{1}$ Peningkatan kadar kolesterol total dalam darah menjadi prediktor yang kuat terjadinya aterosklerosis dan penyakit arteri koroner dan dapat berkembang menjadi penyakit jantung dan pembuluh darah. ${ }^{2}$ Berdasarkan World Health Statistic 2012 angka kematian karena penyakit jantung dan pembuluh darah di Indonesia pada 100.000 penduduk dengan usia 30-70 tahun adalah 308 kasus. ${ }^{3}$ Berdasarkan Profil Kesehatan Provinsi Jawa Tengah tahun 2012 penyakit jantung dan pembuluh darah merupakan kasus tertinggi yaitu sebesar 806.208 kasus $(66,51 \%)$ dari total 1.212.167 kasus penyakit tidak menular. ${ }^{4}$ Rekapitulasi data kesakitan tahun 2012 Dinas Kesehatan Kota Semarang melaporkan terdapat 8.462 kasus penyakit jantung dan pembuluh darah dengan rentang umur 15-64 tahun. ${ }^{5}$

Berdasarkan hasil Riskesdas 2013, penduduk >15 tahun yang memiliki kadar kolesterol total di atas nilai normal yaitu sebanyak $35,9 \%$. Berdasarkan jenis kelamin dan tempat tinggal didapatkan bahwa proporsi penduduk dengan kadar kolesterol di atas normal pada perempuan $(39,6 \%)$ lebih tinggi dibandingkan pada laki-laki $(30,0 \%)$, dan di daerah perkotaan lebih tinggi dibandingkan daerah perdesaan. ${ }^{6}$

Berdasarkan hasil Riskesdas 2013 dijelaskan bahwa prevalensi penyakit jantung koroner meningkat seiring bertambahnya umur, tertinggi pada kelompok umur 65-74 tahun yaitu sebesar $3,6 \%{ }^{6}$

Faktor yang mempengaruhi kadar kolesterol total, antara lain usia jenis kelamin dan aktifitas fisik. Prevalensi penyakit jantung koroner pada perempuan lebih tinggi dibandingkan pada laki-laki yaitu sebesar $1,6 \% .^{6}$ Wanita postmenopause memiliki rerata kadar kolesterol total lebih tinggi 19\% daripada rerata kadar kolesterol total pada wanita pre-menopause. ${ }^{7}$ Pada wanita menopause terjadi penurunan produksi hormon estrogen, karena menurunnya produksi hormon estrogen dapat menyebabkan kadar kolesterol total meningkat. ${ }^{7}$

Aktifitas fisik yang rendah berpengaruh terhadap kejadian penyakit kardiovaskuler. Pada sebuah penelitian menunjukkan bahwa pekerja kantoran memiliki status gizi lebih dengan pola makan yang kurang baik dan aktifitas fisik yang kurang aktif. Aktifitas fisik dan pola makan merupakan salah satu faktor yang dapat mempengaruhi kadar kolesterol darah dalam tubuh. ${ }^{8}$ Angka mortalitas kejadian penyakit jantung koroner banyak dipengaruhi oleh pola sedentary lifestyle penderitanya. ${ }^{9}$

Kadar kolesterol total juga dipengaruhi oleh asupan. Salah satu alternatif yang dapat menurunkan kadar kolesterol adalah dengan cara pengaturan diet. Pengaturan diet yang dianjurkan adalah dengan cara membatasi konsumsi makanan yang mengandung kolesterol dan lemak, terutama lemak jenuh yang tinggi. Selain itu, untuk menurunkan kadar kolesterol juga dianjurkan meningkatkan konsumsi sayuran dan buah. ${ }^{10}$ Salah satu buah yang dapat menurunkan kadar kolesterol atau bersifat hipokolesterolemik adalah buah bengkuang.

Bengkuang adalah umbi-umbian yang sering dikonsumsi oleh masyarakat. Bengkuang mudah didapatkan karena masa panen bengkuang tidak tergantung musim dan juga harga bengkuang yang dijual dipasaran sangat terjangkau. Saat ini, pemanfaatan buah bengkuang banyak digunakan dalam bidang kecantikan, tetapi masih sangat sedikit dimanfaatkan pada bidang kesehatan. Sari bengkuang adalah hasil olahan bengkuang yang diperoleh dengan cara menghaluskan bengkuang menggunakan juicer untuk diambil airnya (sari) yang dapat memudahkan seseorang untuk mengonsumsi buah bengkuang. Dari sebuah penelitian ditemukan kandungan sari bengkuang (Pachyrrhizus erosus) per 100 gram mengandung senyawa polifenolat $3,063 \mathrm{mg} / \mathrm{kg}$, flavonoid $2,669 \%$, alkaloid $1,517 \%$, vitamin B1 $0,07 \mathrm{mg}$, vitamin C $26 \mathrm{mg}$, karbohidrat $13 \mathrm{gr}$, besi $0,8 \mathrm{mg}$, protein 1,6 gr, energi $53 \mathrm{kal}^{11}$

Serat pangan yang terkandung dalam bengkuang memungkinkan untuk dikonsumsi sebagai bahan pangan yang dapat menurunkan kolesterol. Konsumsi makanan tinggi serat dapat menurunkan risiko penyakit kardiovaskuler melalui mekanisme pengaturan konsentrasi lipid dalam darah, yaitu menghambat pembentukan misel dan pengikatan asam empedu, meningkatkan pengeluaran asam empedu melalui feses, dan menghasilkan senyawa asam lemak rantai pendek sebagai hasil fermentasi serat di kolon yang dapat menurunkan sintesis kolesterol. ${ }^{12}$

Penelitian dengan menggunakan tikus putih yang telah dinaikkan kolesterolnya, menunjukkan bahwa pemberian $2 \mathrm{ml}$ sari bengkuang selama 21 hari dapat menurunkan kadar kolesterol total sebesar $28,25 \% .{ }^{11}$ Penelitian pada manusia dengan memberikan sari bengkuang belum pernah dilakukan sebelumnya, oleh karena itu, peneliti ingin melakukan penelitian mengenai 
pengaruh pemberian sari bengkuang terhadap kadar kolesterol total pada wanita.

\section{METODE PENELITIAN}

Penelitian ini merupakan penelitian true experiment dengan rancangan control group pre test - post test. Variabel bebas dalam penelitian ini adalah pemberian sari bengkuang, variabel terikat adalah kadar kolesterol total wanita, dan variabel perancu adalah asupan zat gizi selama intervensi. Pelaksanaan penelitian telah mendapat persetujuan dari Komite Etik Fakultas Kedokteran Universitas Diponegoro melalui terbitnya Ethical Clearance.

Subjek penelitian merupakan karyawati Kantor Wilayah Dirjen Perbendaharaan (DJPB) Jawa Tengah dan kantor Badan Pertanahan Kota Semarang. Kriteria inklusi penelitian ini adalah wanita berusia 40-50 tahun, memiliki kadar kolesterol total $200-239 \mathrm{mg} / \mathrm{dl}$, tingkat aktifitas fisik yang kurang aktif, belum mengalami menopause, tidak merokok, tidak sedang mengonsumsi obat antihiperlipidemia selama penelitian, tidak dalam keadaan sakit atau dalam perawatan dokter berkaitan dengan penyakit jantung koroner, diabetes melitus, hipertensi, gagal ginjal, dan penyakit kronik lainnya, dan tidak sedang hamil atau menyusui. Prosedur pertama dalam penelitian ini adalah memberikan penjelasan tentang tujuan penelitian, metode, risiko dan ketidaknyamanan yang akan dialami serta keuntungan yang diperoleh subjek penelitian. Pengambilan data sampel termasuk pemeriksaan darah dilakukan setelah mendapat persetujuan dari subjek dengan mengisi informed consent. Semua informasi dan data dari penelitian ini hanya dipakai untuk keperluan ilmiah dan kode maupun identitas subjek sangat dirahasiakan untuk umum. Data yang diambil dalam penelitian ini antara lain data umum subjek, aktifitas fisik dan asupan zat gizi.

Data umum subjek mencakup data berat badan yang ditimbang menggunakan timbangan digital dan tinggi badan yang diukur menggunakan microtoise untuk melihat status gizi subjek penelitian. Data status gizi dihitung menggunakan rumus hitung IMT dan dikategorikan dalam 3 kelompok, yaitu normal, overweight, dan obesitas. ${ }^{13}$ Tidak ada pembatasan status gizi subjek penelitian. Dalam penelitian ini, pekerjaan semua subjek penelitian sama, yaitu karyawati. Data aktifitas fisik dikumpulkan menggunakan kuesioner aktifitas fisik Baecke (1982). Aktifitas fisik yang dimaksud adalah aktifitas fisik saat berolahraga dan pada waktu luang. ${ }^{14}$ Aktifitas fisik subjek dihitung menggunakan rumus indeks aktifitas fisik olahraga dan aktifitas waktu luang.
Aktifitas fisik dikategorikan dalam 5 kelompok, yaitu sangat aktif, aktif, cukup aktif, kurang aktif, dan sangat tidak aktif. Subjek penelitian yang memenuhi kriteria inklusi adalah subjek yang memiliki aktifitas fisik dalam kategori kurang aktif.

Penentuan subjek dilakukan dengan metode consecutive sampling dan didapatkan sebanyak 96 orang bersedia diambil darahnya untuk proses skrining awal dan diperoleh sebanyak 32 orang yang memenuhi kriteria inklusi penelitian kemudian dipilih dengan menggunakan metode simple randomization sesuai dengan jumlah sampel minimal, yaitu 28 orang untuk menjadi subjek penelitian. Subjek yang memenuhi kriteria inklusi dibagi menjadi 2 kelompok, yaitu kelompok perlakuan dan kelompok kontrolyang terdiri dari 14 orang untuk masing-masing kelompok.Tidak ada subjek yang drop out dalam penelitian ini. Kelompok perlakuan diberikan sari bengkuang sebanyak $\pm 250 \mathrm{ml} /$ haridan kelompok kontrol mendapatkan plasebo berupa air sirup rendah kalori sebanyak $\pm 250 \mathrm{ml} /$ hari. Pemberian sari bengkuang dan plasebo dilakukan selama 21 hari.

Sari bengkuang didapatkan dari buah bengkuang seberat 320 gram yang telah dikupas dan dicuci bersih. Setelah itu buah bengkuang diambil sarinya dengan menggunakan juicer dengan merk "Cosmos" yang menghasilkan \pm 250 $\mathrm{ml}$ sari bengkuang. Sari bengkuang dikemas dalam gelas plastik yang ditutup rapat dengan menggunakan alat cup sealer. Kandungan zat gizi dalam sari bengkuang diujikan di UPT Laboratorium Pangan Universitas Muhammadiyah Semarang (UNIMUS). Berdasarkan hasil uji yang dilakukan, sari bengkuang yang berasal dari 320 gram buah bengkuang mengandung senyawa oligosakarida $44,04 \mathrm{gr}$, flavonoid $26,455 \%$, serat kasar 3,942 gram dan vitamin C 13,86 gr. Plasebo terbuat dari 2 sdm sirup rendah kalori yang ditambahkan air sebanyak $200 \mathrm{ml}$.

Variabel terikat dalam penelitian ini adalah kadar kolesterol total. Data kadar kolesterol total diambil oleh pihak laboratorium melalui pembuluh darah vena setelah subjek penelitian berpuasa \pm 10 jam. Metode pengukuran kadar kolesterol total menggunakan metode Cholesterol Oxidase Phenol Amino Phenazone (CHOD-PAP). Sampel darah diambil sebanyak 2 kali, yaitu 2 hari sebelum intervensi dan 1 hari setelah intervensi (hari ke-22) untuk mengetahui kadar kolesterol total sebelum dan setelah intervensi. Kadar kolesterol total menggunakan satuan $\mathrm{mg} / \mathrm{dl}$. 
Varibel perancu dalam penelitian ini adalah asupan zat gizi, yaitu karbohidrat, protein, lemak, kolesterol, serat dan vitamin C yang berasal dari konsumsi makanan dan minuman selama intervensi dan dicatat menggunakan formulir food recall 24 jam. Data asupan zat gizi yang diperoleh dalam bentuk URT dan dikonversikan ke dalam satuan gram, kemudian dihitung menggunakan programnutrisoft. Kepatuhan subjek mengonsumsi sari bengkuang dicatat dengan menggunakan formulir kepatuhan.

Data yang diperoleh diuji normalitasnya menggunakan uji Saphiro-Wilk. Gambaran karakteristik subjek dianalisis dengan analisis deskriptif. Perbedaan kadar kolesterol total sebelum intervensi pada kedua kelompok berdistribusi normal dan diuji menggunakan independent $t$-test. Perbedaan kadar kolesterol total sebelum dan setelah intervensi pada kedua kelompok berdistribusi normal dan diuji dengan dependent t-test, sedangkanperbedaan penurunan kadar kolesterol total kedua kelompok berdistribusi tidak normal dan dilakukan uji MannWhitney.Semua uji yang dilakukan menggunakan tingkat kepercayaan $95 \%$.

\section{HASIL PENELITIAN \\ Karakteristik Subjek}

Karakteristik Subjek yang terdiri dari gambaran umum dan status gizi disajikan dalam tabel 1 .

Tabel 1. Karakteristik Subjek

\begin{tabular}{|c|c|c|c|c|c|c|}
\hline \multirow[t]{2}{*}{ Variabel } & \multicolumn{3}{|c|}{$\begin{array}{c}\text { Perlakuan } \\
(n=14)\end{array}$} & \multicolumn{3}{|c|}{$\begin{array}{c}\text { Kontrol } \\
(n=14)\end{array}$} \\
\hline & Mean \pm SD & $\mathbf{n}$ & $\%$ & Mean \pm SD & $\mathbf{n}$ & $\%$ \\
\hline Umur (40-50 thn) & $47,64 \pm 3,08$ & 14 & 50 & $44,57 \pm 3,96$ & 14 & 50 \\
\hline \multicolumn{7}{|l|}{ Status Gizi } \\
\hline Normal (18,5-22,9 kg/m²) & & 2 & 7,1 & & 4 & 14,3 \\
\hline Overweight $\left(23-24.9 \mathrm{~kg} / \mathrm{m}^{2}\right)$ & $26,05 \pm 2,67$ & 3 & 10,7 & $26,52 \pm 5,56$ & 3 & 10,7 \\
\hline Obesitas $\left(>25 \mathrm{~kg} / \mathrm{m}^{2}\right)$ & & 9 & 32,1 & & 7 & 25 \\
\hline \multicolumn{7}{|l|}{ Aktifitas Fisik } \\
\hline Kurang Aktif (1,5-2,5) & $1,53 \pm 0,01$ & 14 & 50 & $1,53 \pm 0,14$ & 14 & 50 \\
\hline
\end{tabular}

Umur pada kedua kelompok berada pada rentang 40-50 tahun. Sebagian besar subjek memiliki status gizi obesitas pada kelompok perlakuan $(32,1 \%)$ dan kelompok kontrol $(25 \%)$. Aktifitas fisik pada kedua kelompok termasuk dalam kategori kurang aktif dengan rata-rata 1,53 $(1,5-2,5)$. Seluruh subjek pada kedua kelompok perlakuan bersifat homogen.

\section{Asupan Zat Gizi Kelompok Perlakuan dan Kontrol Selama Intervensi}

Data asupan energi, karbohidrat, protein, lemak, serat, vitamin $\mathrm{C}$, dan kolesterol kedua kelompok selama intervensi disajikan dalam Tabel 2.

Tabel 2. Asupan Makan Kelompok Perlakuan dan Kontrol selama Intervensi

\begin{tabular}{lccc}
\hline \multicolumn{1}{c}{ Variabel } & Perlakuan $(\mathbf{n = 1 4})$ & Kontrol $(\mathbf{n}=\mathbf{1 4})$ & p \\
\cline { 2 - 3 } & Rerata \pm SD & Rerata \pm SD & $0,223^{\mathrm{a}}$ \\
Asupan Energi (kkal) & $1218,07 \pm 283,12$ & $1274,36 \pm 173,94$ & $0,330^{\mathrm{b}}$ \\
Asupan Protein (g) & $41,96 \pm 10,55$ & $38,58 \pm 7,20$ & $0,890^{\mathrm{b}}$ \\
Asupan Lemak (g) & $47,26 \pm 14,25$ & $46,46 \pm 15,93$ & $0,162^{\mathrm{b}}$ \\
Asupan Karbohidrat (g) & $160,25 \pm 47,12$ & $181,19 \pm 27,33$ & $0,909^{\mathrm{a}}$ \\
Asupan Kolesterol (g) & $182,26 \pm 111,31$ & $173,96 \pm 45,97$ & $0,247^{\mathrm{b}}$ \\
Asupan Serat (g) & $8,81 \pm 2,62$ & $7,71 \pm 2,24$ & $0,306^{\mathrm{b}}$ \\
Asupan Vitamin C (mg) & $52,18 \pm 22,15$ & $42,52 \pm 26,61$ & \\
\hline
\end{tabular}

$\mathrm{a}=$ Mann-Whitney, $\mathrm{b}=$ Independent t-test

Pada Tabel 2 menunjukkan bahwa tidak terdapat perbedaan rerata asupan zat gizi yang bermakna selama intervensi antar 2 kelompok
( $>0,05)$. Rerata asupan zat gizi kelompok kontrol lebih rendah dibandingkan dengan kelompok perlakuan. 


\section{Perbedaan Kadar Kolesterol Total Sebelum dan Setelah Intervensi}

Tabel 3. Perbedaan Kadar Kolesterol Total Sebelum dan Setelah Intervensi

\begin{tabular}{|c|c|c|c|}
\hline Variabel & $\begin{array}{c}\text { Perlakuan }(n=14) \\
\text { Rerata } \pm \text { SD }\end{array}$ & $\begin{array}{c}\text { Kontrol }(n=14) \\
\text { Rerata } \pm \text { SD }\end{array}$ & $\mathbf{p}^{\mathbf{b}}$ \\
\hline Kolesterol Total (mg/dl) & & & \\
\hline Pre-Test & $222,64 \pm 10,42$ & $220,14 \pm 10,64$ & 0,535 \\
\hline Post-Test & $202,64 \pm 14,73$ & $233,07 \pm 19,46$ & $0,000^{*}$ \\
\hline$\Delta$ & $-20,00 \pm 10,95$ & $12,93 \pm 13,66$ & $0,000^{*}$ \\
\hline $\mathbf{p}^{\mathbf{a}}$ & $0,000^{*}$ & $0,004^{*}$ & \\
\hline
\end{tabular}

Dari hasil diatas dapat disimpulkan bahwa ada perbedaan yang bermakna sebelum dan setelah diberikan intervensi baik pada kelompok perlakuan maupun kelompok kontrol $(\mathrm{p}<0,05)$. Rerata penurunan kadar kolesterol total yang terjadi pada kelompok perlakuan adalah sebanyak $20,00 \pm 10,95 \mathrm{mg} / \mathrm{dl} \quad(8,98 \%)$ sedangkan pada kelompok kontrol juga terdapat perbedaan kadar kolesterol total yang mengalami peningkatan sebesar 12,93 $\pm 13,66 \mathrm{mg} / \mathrm{dl}(5,87 \%)$.

Pada kelompok perlakuan, semua subjek penelitian mengalami penurunan kadar kolesterol total. Pada kelompok kontrol terdapat 2 orang subjek tidak mengalami perubahan kadar kolesterol total dan 12 orang lainnya mengalami peningkatan kadar kolesterol total. Perbedaan rerata perubahan kadar kolesterol total antar 2 kelompok didapatkan bahwa ada perbedaan bermakna rerata perubahan kadar kolesterol total antara kelompok perlakuan dan kelompok kontrol $(\mathrm{p}<0,05)$.

\section{PEMBAHASAN}

Karakteristik subjek dalam penelitian ini wanita berusia 40-50 tahun yang belum mengalami menoupase dengan kadar kolesterol 200-239 mg/ dL dan memiliki aktifitas fisik yang sama, yaitu dalam kategori kurang aktif . Menurut hasil survey yang dilakukan di Thailand, sebanyak 50,3\% wanita hiperkolesterolemia berada pada kelompok umur 30-49 tahun. ${ }^{15}$ Pada usia subur, wanita terlindungi oleh hormon esterogen yang berperan dalam mencegah terjadinya plak arteri dengan meningkatkan kadar kolesterol HDL dan menurunkan kadar kolesterol LDL yang secara langsung akan berpengaruh terhadap kadar kolesterol total. Wanita yang memasuki masa pre menopause hingga menopause, terjadi penurunan produksi hormon esterogen di dalam tubuh, yang dapat menyebabkan peningkatan kadar kolesterol total dalam darah dan penyakit jantung. ${ }^{16}$

Pada penelitian ini sebagian besar subjek penelitian pada kedua kelompok memiliki status gizi obesitas. Status gizi overweight dan obesitas memiliki risiko terjadinya penyakit jantung koroner lebih besar dibandingkan dengan status gizi underweight dan normal. Penderita obesitas mengalami kelainan hormon leptin yang dapat menggangu mengontrol nafsu makan dan berdampak pada akumulasi jaringan lemak yang berlebihan dan terjadi gangguan metabolisme lipoprotein yang ditandai dengan kadar trigliserida dan ester kolesterol meningkat. ${ }^{17}$ Peningkatan trigliserida yang besar dalam sirkulasi darah menyebabkan kadar kolesterol yang dibawa oleh Very Low Density Lipoprotein (VLDL) dan LDL meningkat, hal ini dapat menyebabkan terjadinya penumpukan lemak berlebihan didalam tubuh dan meningkatkan kadar kolesterol total. Risiko hiperkolesterolemia pada wanita meningkat seiring bertambahnya usia dan berat badan. ${ }^{17,18}$

Berdasarkan data aktifitas fisik yang dikumpulkan menggunakan kuesioner aktifitas fisik Baecke, aktifitas fisik subjek penelitian termasuk dalam kategori kurang aktif. Pada sebuah penelitian menerangkan bahwa risiko terkena penyakit jantung yang lebih tinggi terdapat pada individu yang memiliki aktifitas fisik rendah, dibandingkan dengan individu yang aktif melakukan aktifitas fisik. ${ }^{19}$

Dari data recall asupan zat gizi subjek didapatkan hasil bahwa tidak ada perbedaan asupan energi, karbohidrat, protein, lemak, kolesterol, serat dan vitamin $\mathrm{C}$ antara kelompok perlakuan dan kontrol.

Berdasarkan hasil analisis statistik, tidak terdapat perbedaan yang bermakna terhadap kadar kolesterol total sebelum intervensi pada kedua kelompok.Hasil analisis statistik setelah intervensi menunjukkan bahwa ada perbedaan yang bermakna sebelum dan setelah diberikan intervensi baik pada kelompok perlakuan maupun kelompok kontrol. Rerata kadar kolesterol total pada kelompok perlakuan mengalami penurunan kadar kolesterol total secara bermakna sebesar $20,00 \pm 10,95 \mathrm{mg} / \mathrm{dl}$ atau sebesar $8,98 \%$.

Penurunan kadar kolesterol pada kelompok perlakuan diyakini dipengaruhi karena adanya 
tambahan asupan vitamin $\mathrm{C}$ dan serat yang terkandung dalam sari bengkuang. Vitamin C merupakan salah satu antioksidan yang memiliki sifat anti-aterogenik yang berfungsi untuk mengurangi oksidasi kolesterol.Vitamin C merupakan antioksidan larut air yang sangat efektif dalam plasma darah. Vitamin $\mathrm{C}$ yang terkandung dalam sari bengkuang dapat membantu reaksi hidroksilasi dalam pembentukan asam empedu yang dapat meningkatkan ekskresi kolesterol dalam tubuh sehingga dapat menurunkan kadar kolesterol total dalam darah. ${ }^{20}$

Serat memiliki fungsi yang dapat mencegah dan mengobati beberapa penyakit yang berhubungan dengan saluran pencernaan dan menurunkan kolesterol. ${ }^{18}$ Buah bengkuang mengandung serat larut air yang dapat mengurangi absorbsi lemak dalam usus sehingga dapat menurunkan kadar kolesterol. Mekanisme serat larut air dalam menurunkan kadar kolesterol, yaitu serat makanan menunda pengosongan lambung yang dapat membatasi asupan kalori yang masuk, meningkatkan ketebalan lapisan intestinal yang berfungsi sebagai tempat absorpsi lipid, serta memberikan efek hipomotilitas untuk memperlambat proses pencernaan dan absorpsi zat gizi. ${ }^{21}$ Serat juga meningkatkan pengeluaran cairan empedu. Cairan empedu yang telah terikat oleh serat tidak dapat direabsorpsi dan diresirkulasi melalui siklus enterohepatik. Di usus serat akan difermentasi bakteri untuk memproduksi asam asetat propionate dan butirat yang berfungsi untuk menghambat sintesis kolesterol, akibatnya cairan empedu ini akan terus ke usus besar untuk disekresikan bersama feses. ${ }^{22} \mathrm{Pada}$ penelitian sebelumnya menggunakan tikus putih yang telah dinaikkan kadar kolesterolnya dan diberikan sari bengkuang sebanyak $2 \mathrm{ml}$ selama 21 hari dapat menurunkan kadar kolesterol total sebesar $28,25 \% .^{11}$

Rerata kadar kolesterol total pada kelompok kontrol juga mengalami perbedaan yang bermakna, tetapi pada kelompok kontrol mengalami peningkatan sebesar 12,93 $\pm 13,66$ $\mathrm{mg} / \mathrm{dl}$ atau sebesar 5,87\%. Hal ini kemungkinan disebabkan karena pada kelompok kontrol tidak terdapat peningkatan asupan vitamin $\mathrm{C}$ dan serat seperti pada kelompok perlakuan yang berasal dari sari bengkuang. Dari hasil recall asupan zat gizi selama intervensi, rerata asupan serat dan vitamin $\mathrm{C}$ pada kelompok kontrol sebesar 7,71 $\pm 2,24 \mathrm{~g}$ dan $42,52 \pm 26,6 \mathrm{mg}$. Anjuran kecukupan serat harian yang direkomendasikan oleh American DieteticAssociation (ADA) sebesar $20 \mathrm{~g} / \mathrm{hari}$ atau berdasarkan Dietary Reference Intake (DRI) setara dengan $14 \mathrm{~g} / 1000 \mathrm{kkal}^{23}$. Anjuran kecukupan vitamin $\mathrm{C}$ harian yang direkomendasikan oleh American DieteticAssociation (ADA) sebesar 75 $\mathrm{mg} /$ hari atau berdasarkan Dietary Reference Intake (DRI) setara dengan63,6 mg/1000 kkal. ${ }^{24}$ Rerata asupan serat dan vitamin $\mathrm{C}$ pada kelompok kontrol masih kurang jika dibandingkan dengan anjuran yang direkomendasikan per $1000 \mathrm{kkal}$.

Asupan serat yang rendah merupakan salah satu penyebab tingginya kadar kolesterol total. Hal ini sesuai dengan hasil penelitian yang dilakukan pada wanita dan pria di Jepang, dimana pada kelompok wanita, nilai media asupan serat terendah adalah $7,4 \mathrm{~g} / \mathrm{hr}$ dan tertinggi $13,8 \mathrm{~g} / \mathrm{hr}$, berhasil membuktikan bahwa rendahnyaasupan serat berhubungan dengan peningkatan kadar kolesterol total dan risiko kematian akibat penyakit jantung dan pembuluh darah. ${ }^{25}$ Konsumsi serat diketahui dapat meningkatkan ekskresi lemak melalui feses sebanyak 2-4 g/hari. ${ }^{21}$

Asupan kolesterol pada kelompok kontrol dapat mempengaruhi peningkatan kadar kolesterol total dalam darah. Rata-rata peningkatan asupan kolesterol $100 \mathrm{mg} /$ hari dapat meningkatkan serum kolesterol 2-3 mg/dl. ${ }^{1}$ Faktor aktifitas fisik subjek yang kurang aktif juga dapat mempengaruhi peningkatan kadar kolesterol total. Pada sebuah penelitian menyebutkan bahwa individu yang rutin melakukan aktivitas fisik memiliki tingkat efisiensi metabolisme TG-RL (triglyceride-rich lipoprotein) yang lebih baik sehingga kadar kolesterol total dan trigliserida cenderung lebih rendah dibandingkan individu dengan sedentary lifestyle. ${ }^{26}$

\section{SIMPULAN}

Terdapat penurunan kolesterol total yang bermakna sebesar $20 \mathrm{mg} / \mathrm{dl}$ setelah pemberian sari bengkuang dari 320 gram buah bengkuang

\section{SARAN}

Perlu dilakukan pengambilan data asupan gizi sebelum intervensi.

\section{DAFTAR PUSTAKA}

1. Krummel DA. Medical Nutrition Therapy for Cardiovascular Disease. In: Mahan LK, Escottstump S, editors. Krauses's Food, Nutrition, and Diet Therapy. 13th ed. USA: Saunders;2012.p.742-58.

2. Carolt TB. Penyakit Aterosklerotik koroner. In : Sylvia A. Price, Lorraine M. Wilson. Patofisiologi Konsep Klinis Proses-Proses Penyakit. Edisi 6. Jakarta: Penerbit buku kedokteran EGC; 2006.p.576 612

3. World Health Statistics 2012. World Health Organization [serial online] [cited 2014 Maret 19] 
Available from:

URL:http://www.who.int/gho/publications/world_ health_statistics/EN_WHS2012_Full.pdf

4. Profil Kesehatan Provinsi Jawa Tengah 2012 [serial online] [cited 2014 Maret 19] Available from: URL:

http://www.dinkesjatengprov.go.id/dokumen/2013/ SDK/Mibangkes/profil2012/BAB_I-

VI_2012_fix.pdf

5. Dinas Kesehatan Kota Semarang. Laporan Rekapitulasi Data Kesakitan Tahun 2012. [serial online] Available from: URL:

http://www.dinkesjatengprov.go.id/dokumen/2013/ SDK/Mibangkes/profil2012/BAB_IVI_2012_fix.pdf

6. Badan Penelitian dan Pengembangan Kesehatan. Laporan Hasil Riset Kesehatan Dasar Nasional 2013 . Jakarta: Kementerian Kesehatan Republik Indonesia; 2013

7. J L Jenner, J M Ordovas, S Lamon-Fava, M M Schaefer, P W Wilson, W P Castelli and E J Schaefer.1993.Effects of age, sex, and menopausal status on plasma lipoprotein(a) levels. The Framingham Offspring Study. Circulation Vol 87, No 4 April 1993

8. Dewi, Ade Chintya Nirmala. Hubungan Pola Makan, Aktivitas Fisik, Sikap dan PengetahuanTentang Obesitas dengan Status Gizi Pegawai NEgeri Sipil di Kantor Dinas Kesehatan Provinsi Jawa Timur. Program Studi: Kesehatan Masyarakat

9. Barengo N, Hu G, Lakka T. Low Physical Activity as A Predictor for Total and Cardiovascular Disease Mortality in Middle-Aged Men and Women in Finland. Eur Heart J 2004;25:22042211.

10. Kathleen MB, Mayes PA. Sintesis, Transpor dan Ekskresi Kolesterol. In: Murray RK, Granner DK, Mayes PA, Rodwell VW, editors. Biokimia Harper. Edisi 27. Jakarta: Penerbit Buku Kedokteran EGC; 2009.p.239-49.

11. Setyadi, Ahmad Wasis,Junianto F, Erni Yulianti. Pengaruh Sari Bengkuang (Pachryrrhizua Erosus) Terhadap Penurunan Kolesterol Pada Tikus Putih (Rattus Norvergicus) Di Laboratorium Kimia Universitas Muhammadiyah Malang. 2013

12. Mette Kristensen, Morten G Jensen, Julie Aarestrup, Kristina EN Petersen, Lise Søndergaard, Mette S Mikkelsen2 and Arne Astrup. Flaxseed dietary fibers lower cholesterol and increase fecal fat excretion, but magnitude of effect depend on food type. Nutrition \& Metabolism 2012. [serial online] [cited 2014 Maret 19] Available from:

URL:http://www.nutritionandmetabolism.com/con tent $/ 9 / 1 / 8$

13. Supariasa, IDN., Bachyar B., Ibnu F. Dalam : Ester M,editor. Penilaian Status Gizi. Cetakan I. Jakarta- Penerbit Buku Kedokteran : EGC. 2002. p.60-61
14. Baecke JAH, Burema J Frijters ER. A short questionnaire for the measurement of habitual physical activity in epidemiological studies. Am J Clin Nutr. 1982; 36: 936-942.

15. Le D, Garcia A, Lohsoonthorn V, Williams MA. Prevalence and Risk Factors of Hypercholesterolemia among Thai Men and Women Receiving Health Examinations. Southeast Asian J Trop Med Public Health. 2006; 3(5). p. 1005-1014.

16. Soeharto I. Pengaruh Usia dan Gender terhadap Kolesterol. Dalam : Serangan Jantung dan Stroke. Jakarta : PT Gramedia Pustaka Utama; 2004.p. 168-178

17. Mann J, Stewart A.T. Essential of Human Nutrition Third Edition. USA : Oxford University. In press 2007.p.637.

18. Kathleen MB, Mayes PA. Pengangkutan \& penyimpanan lipid. In: Murray RK, Granner DK, Mayes PA, Rodwell VW, editors. Biokimia Harper. Edisi Jakarta: Penerbit Buku Kedokteran EGC; 2009.p.225-38.

19. Miller M. Dyslipidemia and Cardiovascular Risk: The Importance of Early Prevention. QJ Med 2009;102:657-67.

20. Riccardi G, Rivellese A, Williams C. The Cardiovascular System. In: Gibney MJ, Macdonald IA, Roche HM, editors. Nutrition and Metabolism. Second Edition. United States of America: Blackwell publishing; 2011. P. 247-71.

21. Lisa Brown, Bernard Rosner, walter W, Frank M sacks. Cholesterol lowering effects of dietary fiber: a meta-analysis. [serial online] 1999. 69:30-4. Available from: http://ajcn.nutrition.org/content/69/1/30.full.pdf+ht $\mathrm{ml}$

22. Gropper SS, Smith JL, Groff JL. Advanced Nutrition and Human Metabolism. 5th ed. United States of America: Wadsworth;2009.p.115-16

23. Dreher ML. Dietary Fiber Overview. Indiana : Mead JohnsonNutritionals/Bristol-Myers Squibb Company, Evansville. 2001

24. Diaz DF Gracia, dkk. Vitamin C Inhibits Leptin Secretion and Some Glucose/Lipid Metabolic Pathways in Primary Rat Adipocytes. Journal of Molecular Endocrinology 2010;45,33-43

25. Eshak ES, Iso H,Date C, Kikuchi S, Watanabe Y, Wada Y, et al. Dietary Fiber Intake is associated with reduced risk of mortality from cardiovascular disease among Japanese men and women. J. Nutr. 2010. 140: 1445-1453.

26. Ali Al-Mamari. Atherosclerosis and Physical Activity. Oman Medical Journal. Vol. 3. 2009. 